Arab Univ. J. Agric. Sci., Ain Shams Univ., Cairo, Egypt

28(4), 1041-1053, 2020

Website: http://ajs.journals.ekb.eg

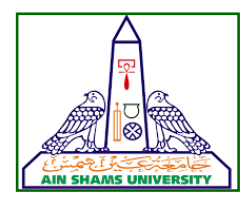

1041

\title{
Effect of Nozzles Design on the Performance of Impact Sprinklers in Sprinkler Irrigation System
}

\author{
Engy MM Khair ${ }^{1 *}$, Mahmoud M Hegazi ${ }^{2}$, Khaled F El-Bagoury ${ }^{2}$, \\ Waael M Sultan ${ }^{1}$ \\ 1- Field Irrigation and Drainage Engineering Researches Dept, Agric Engineering Research \\ Institute, ARC, Dokki, Egypt \\ 2- Agric. Engineering Dept, Fac of Agric, Ain Shams Univ, P.O. Box 68, Hadayek Shoubra 11241, \\ Cairo, Egypt
}

${ }^{*}$ Corresponding author: engymosalem@egr.asu.edu.eg

Received 29 July, 2020

Accepted 10 October, 2020

\begin{abstract}
Water is limited resource. This is considered to be one of the main challenges for future water policy. Saving water and energy is a requirement to ensure the viability of pressurized irrigation systems. Designing and optimizing sprinkler irrigation systems are mainly based on achieving appropriate hydraulic performance. Spray nozzles being very often a critical component in determining the final quality of the product or the sprinkler irrigation efficiency process. The engineering design factors of sprinkler affect sprinkler system performance. So, this study focuses on some engineering design factors (three different nozzle characteristics (1,2 and 3) and operating pressures from 150 to $250 \mathrm{kPa}$ ), comparing with designed nozzle (No 4) to improve brass impact sprinkler performance. This study sited on Giza region at National Laboratory for testing the components of irrigation networks and field drainage, Agricultural Engineering Research Institute AEnRI, Agricultural Research Center ARC. The result of Christiansen uniformity coefficient $\mathrm{CU}$ indicated that designed nozzle No 4 achieving good performance according to American society of Agricultural and Biological Engineers ASABE 2001 starting with operating pressure $150 \mathrm{kPa} 74.05 \%$ while nozzle No 3 starting with $175 \mathrm{kPa}$ achieved $75.23 \%$. Also it was found that nozzle No 4 increasing flow rate by 43.48 $\%$, precipitation rate by $19.92 \%$, rotation speed by $24.96 \%$, decreasing coverage radius by $28.38 \%$ and the jet breaks up sufficiently to achieve an adequate water distribution pattern and obtained good droplet size comparing with nozzle No 3 . It was
\end{abstract}

found that sprinkler layouts $9 \mathrm{~m} \times 9 \mathrm{~m}$ overlapping achieved acceptable uniformity at operating pressure $150 \mathrm{kPa}$. Also the result indicated that nozzle No 4 saved operating time ratio by $26.87 \%$ and decreased over minimum application targeted irrigation depth by $66.7 \%$ at the same overlapping distances and at the same operating pressure 150 $\mathrm{kPa}$.

Keywords: Impact sprinkler irrigation, Nozzle, Operating pressure, Uniformity, Performance

\section{Introduction}

Agriculture is a sector often criticized for its excessive water consumption. Indeed, agriculture is responsible for approximately $70 \%$ of total freshwater withdrawal in the world, mostly through irrigation (FAO 2015).

Robles et al (2017) said that water is limited and precious resource. this research was studying possibility of reducing operating pressure of impact sprinklers nozzle from $300 \mathrm{kPa}$ to $200 \mathrm{kPa}$ (low pressure) without reducing the sprinkler layout by using three treatments resulting from sprinkler type, and working pressure were analyzed (impact sprinkler operating at $300 \mathrm{kPa}$; impact sprinkler at $200 \mathrm{kP}$; and Modified deflecting plate impact sprinkler at 200 $\mathrm{kPa}$. An experimental design was applied to a maize crop during two seasons (2015 and 2016). The results of low pressure sprinkler did not reduce maize grain yield compared to the standard pressure sprinkler. The wind drift and evaporation losses WDEL for the 2016 season was higher for the 
CIS300 (17\%) than for DPIS200 (15\%) and CIS200 (13\%). As nozzle diameter decreases and pressure increases, the number of small diameter drops increases and the number of large diameter drops decreases. The small drops are more likely to be drifted by wind and evaporated.

Jiushen et al (1995) said the for the same pressure discharge characteristic pattern radius for noncircular nozzle is normally shorter than that for circular nozzle; however, a noncircular nozzle gives higher over- lapped uniformity coefficient than a circular nozzle at low pressure because the former discharges more water near the sprinkler than the latter so the researcher studied the effect of the diffuse extent of jets formed by double rectangular nozzles on the sprinkler rotation speed was founded that the speed decreases as the jet diffuse extent increases. In the present work it was assumed that discharge exponent was equal to 0.5 and a single coefficient discharge was $\mathrm{Cd}$ determined for each sprinkler nozzle diameters at different operating pressures. A very slight increase of the $\mathrm{Cd}$ was found as the slot diameter of the sprinkler nozzle increased. (Stambouli et al 2014).

Hedia et al 2017 simulate sprinklers overlapping pattern using single sprinkler distribution pattern resulting uniformity coefficient to be useful for sprinkler irrigation design and analysis the designing of sprinklers overlapping pattern and performance parameters.

This study aims to improve sprinkler performance by developing nozzle characteristic to save operating time and energy. Endorse appropriate uniformity under different overlapping ratio using the prediction HEDIA program to establish it in actual experiment.

\section{Material and Methods}

The experiment was carried out in the National Laboratory for Testing the Components of Irrigation Networks and Field Drainage, Agricultural Engineering Research Institute AEnRI, ARC. An indoor experiment on characterizing water distribution of an individual sprinkler was carried out in accordance with ASABE 2001. Riser pipes were used to locate the sprinkler nozzle at an elevation of $1 \mathrm{~m}$ above the ground level. The individual sprinkler test is controlled by a hydraulic valve equipped with a pressure gauge. Two treatments were designed for this research; nozzle shape and operating pressure each of them for brass type of impact sprinklers was tested at operating pressure from 150 to $250 \mathrm{kPa}$.

\subsection{Materials}

Fig 1 Illustrates schematic diagram of sprinkler layout.

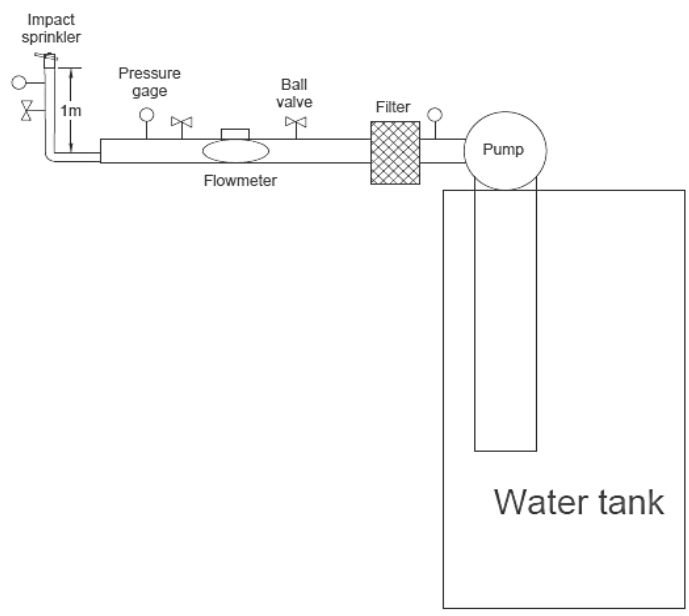

Fig 1. Schematic diagram of individual sprinkler test

\subsection{The studied sprinkler}

\subsection{The tested nozzle}

Fig 2 shows Tested brass impact sprinkler

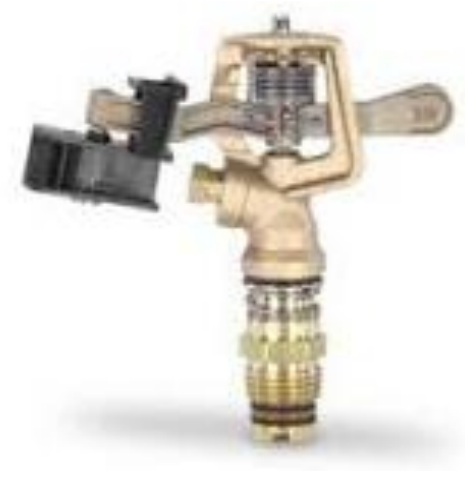

Fig 2. Tested brass impact sprinkler 

sprinkler irrigation system

\begin{tabular}{|l|c|c|c|c|}
\hline \\
\hline
\end{tabular}

Technical description of nozzle No 4:

The nozzle jet angle with the deaf sprinkler arm helps to tighten the water stream coming out of the sprinkler nozzle, along with the nozzle characteristic, which helps to dispel the kinetic energy.

Fig.3. Tested brass nozzle impact sprinkler geometric dimension

\subsection{Simulation Model (HEDIA Program)}

HEDIA computer model 2017 Version 1.0.0.0 size 175 MB used Visual Basic 2012 and Excel 2010 software. This model can quickly compute most types of uniformity coefficients draw sprinkler water distribution pattern and determine the best sprinklers combination shape space depending up on one sprinkler water distribution pattern data, sprinkler effective radius and precipitation at catch cans. Done by calculating of overlapping performance parameters allow selecting the best sprinklers overlapping pattern design. The data can be determined from one radial or quarter part sector of square grid area in lab test. HEDIA model output results involve sprinklers overlapping pattern data, uniformity coefficients of Christiansen, Wilcox, Hart and Karmeli, statistics analysis such as mean, stander deviation, and variance, overlapping linear regression constants or normal fit curve characteristics, water application efficiency, water storage efficiency, deep percolation and others.

\subsection{Methods}

- As the flow rate was increased by increasing the pressure, the precipitation rate was measured. So the sprinklers have been chosen by the Resident based on experience and defining the distance between cans $(1 \mathrm{~m})$. Sprinklers were adapted to spray out of the testing area until the adaptation the testing pressure, then let the sprinklers spray was left all over the served area for at least $1 / 2$ hour.

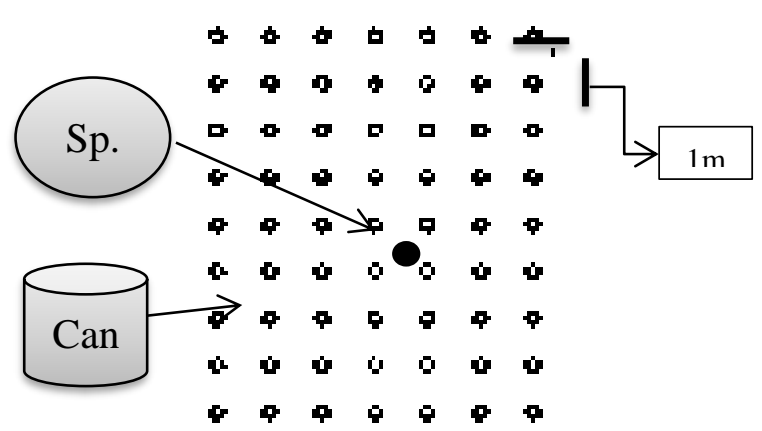

Fig 4. The array precipitation rate cans pattern 
- After resetting of the desired pressure, the nozzle flow rate was measured for each nozzle using hose and tank to collect water from the nozzle. The time of collecting water was recorded for each nozzle. Pre-experiments were determining the orifice discharge coefficient $\mathrm{Cd}$.

$$
\mathbf{C d}=\frac{\mathrm{Q}}{\mathrm{A}(2 \mathrm{gh})^{\mathrm{x}}}
$$

E. Torricelli 1644 Cited by Abdel-Mageed et al 2009

Where: Cd is discharge coefficient dimensionless, $\mathrm{Q}$ flow rate in $\mathrm{m}^{3} / \mathrm{hr}$,

$A$ is orifice cross section area in $\mathrm{m}^{2}$,

$\mathrm{G}$ is gravity acceleration, $9.81 \mathrm{~m} / \mathrm{s}^{2}$,

$\mathrm{h}$ is water head in $\mathrm{m}$,

And $\mathrm{x}$ is constant.

- Maximum droplet diameter measured by three methods (filter paper, oil and volumetric method)

$$
d=1.24 \sqrt[3]{\frac{m}{\rho}}
$$

Abdel-Mageed et al 2009

Where: $\mathrm{d}$ is droplet diameter in $\mathrm{mm}$; $\mathrm{m}$ is droplet mass in $\mathrm{g}$; $\rho$ is water density in $\mathrm{g} / \mathrm{mm}^{3}$.

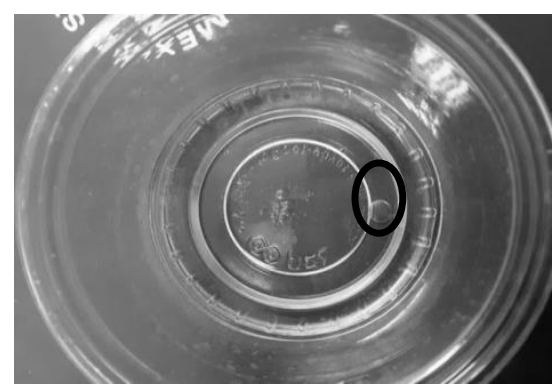

Fig 5. Water droplet size on the oil

- Break-up of jet of water obtain the uniformity of coverage. Generally, break up increases with pressure and presence of slots in the nozzle beside slow rotation sprinklers about 0.67 to 1 rotation per minute of small sprinklers provides good coverage.

$$
\mathbf{P d}=\frac{\mathbf{P}}{10 \times \mathbf{q}^{0.4}}
$$

Dwivedi et al 2015

Where: $P d=$ index for jet break up, $\mathrm{h}=$ pressure head at sprinkler nozzle; $\mathrm{m}$ (meter), $q=$ sprinkler discharge, Ips (liters per second).

If the value of $\mathrm{Pd}$ is 4 , the condition of drop size is considered to be the best and if it is greater than 4 then pressure is being wasted.

- Irrigation uniformity can be used as indicator for describing the performance of the on-farm sprinkler irrigation network. Irrigation uniformity is usually characterized by:

$$
\mathbf{C u}=\left(1-\frac{\sum\left(\mathbf{Z}-\mathbf{Z}^{\prime}\right)}{\mathrm{nZ}^{\prime}}\right) \times 100
$$

Christiansen 1947 cited by Khadra et al 2013

Where: CU is the coefficient of uniformity in \%;

$Z$ is the individual depth of catch observations from uniformity test in $\mathrm{mm}$;

$\mathrm{Z}^{\prime}$ is the mean absolute deviation in $\mathrm{mm}$; and $\mathrm{n}$ is the number of observations in $\mathrm{mm}$. In this study CU was considered for the analysis of the sprinkler networks.

\subsection{Over irrigation percentage calculation}

To achieve the target for irrigation, the minimum application should equal the target application depth. Some areas were received over irrigation. The over irrigation was calculated by assuming that the minimum application is the targeted the irrigation depth. The over irrigation is the difference between the overlapping water application depth in a point and the targeted irrigation depth. Reducing over irrigation realizes two advantages, saving water and energy necessary to pumping this water. (Abdel-Mageed et al 2009).

\section{Result and Discussion}

\subsection{Result of individual sprinkler}

Velocity and coefficient of discharge for different nozzles were calculated and recorded in Table 1.

Table 1. Velocity and coefficient of discharge for nozzle

\begin{tabular}{|c|c|c|c|}
\hline $\begin{array}{c}\text { Nozzle } \\
\text { Number }\end{array}$ & $\begin{array}{c}\text { Orifice } \\
\text { diameter } \\
\text { (m) }\end{array}$ & $\begin{array}{c}\text { Jet } \\
\text { velocity } \\
\text { (m/s) }\end{array}$ & $\begin{array}{c}\text { Coefficient of } \\
\text { discharge } \\
\mathbf{C}_{\mathbf{d}}\end{array}$ \\
\hline $\mathbf{1}$ & 0.0015 & 20.3 & 0.75 \\
$\mathbf{2}$ & 0.0015 & 21.2 & 0.32 \\
$\mathbf{3}$ & 0.0024 & 12.8 & 0.31 \\
$\mathbf{4}$ & .00185 & 15 & 0.26 \\
\hline
\end{tabular}




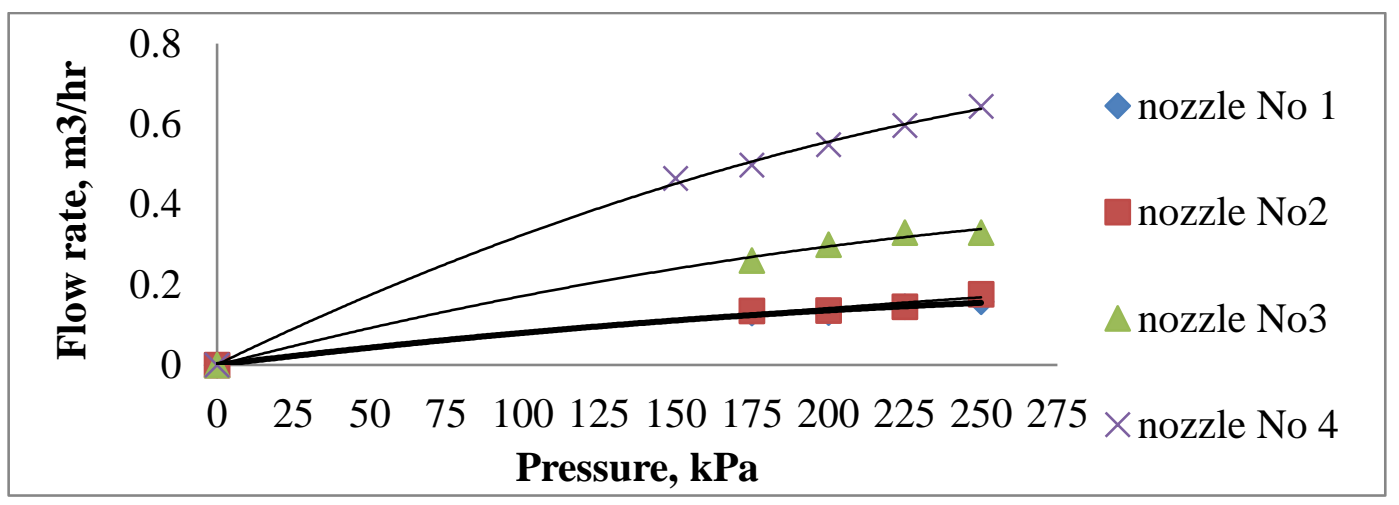

Fig 6. Flow rate at different operating pressure

Table 2. Pressure vs. discharge Exponent at various nozzle types

\begin{tabular}{|c|c|c|c|}
\hline $\begin{array}{c}\text { Nozzle } \\
\text { Number }\end{array}$ & $\begin{array}{c}\text { Discharge } \\
\text { Exponent }\end{array}$ & Reference range & performance \\
\hline 1 & 0.56 & $\mathrm{X}=1$ Laminar Flow & Turbulent Flow \\
2 & 0.7 & $\mathrm{X}=0.75$ Partially Turbulent Flow \\
$\mathrm{X}=0.5$ Turbulent Flow & Partially Turbulent Flow \\
3 & 0.64 & $\mathrm{X}=0.25$ Partially Pressure Compensating & Turbulent Flow \\
4 & 0.72 & $\mathrm{X}=0$ Pressure Compensating & Partially Turbulent Flow \\
\hline
\end{tabular}

Increasing operating pressure, the flow rate increased. The flow rate of Nozzle No 4 was the highest flow rate and the lowest flow was obtained by nozzle No 1. Nozzle No.4 obtained less discharge coefficient than others nozzles. It indicate that not only orifice diameter also nozzle path affected resistance to the flow. The highest flow rate at operating pressure $150 \mathrm{kPa}$ was $0.46 \mathrm{~m}^{3} / \mathrm{hr}$ obtained to slot area profile and the discharge exponent was 0.72 partially turbulent flow. It may be indicator to nozzle characteristics (shape and outlet surface area) not the contraction angle of the nozzle. This is similar to Jiusheng and Kawano 1998, who studied the contraction angle and its effect on sprinkler performance. They found that relation between it and discharge exponent was insignificant so it was taken as 0.5 .

It was found that the value of index of jet break up (4.43) obtained by nozzle No. 3 was found to be exceeding the value of 4 which clearly indicated that the pressure was being wasted and obtained unsuitable droplet size. Also It was found that the value of index of jet break up (3.4) at $150 \mathrm{kPa}$ operating pressure which it was found to be the value between 2 and 4 which clearly indicated that the pressure was being suitable and obtained good droplet size.
Sprinkler rotation speed is one of the variables influencing application intensity and the water distribution pattern. The figure shows that the highest rpm was obtained by nozzle No. 4. It may be because of throw velocity which distracts the water path throughout the nozzle where the diffused jet does not operate the impact arm as efficiently as a smooth jet, resulting in possible rotation problems. The increase in rotation speed with contraction angle may be due to the sprinkler arm receiving less power for a nozzle having a larger contraction angle because the kinetic energy (related to the discharge and initial velocity of the spray stream) formed by a larger contraction angle nozzle is smaller and the spread of the jet exiting the nozzle orifice is increased by the larger contraction angle. The rotation speed (rpm) was affected by the nozzle diameter agree with Osman et al (2014).

Also the rotation time increases as the pressure increases. According to Jiusheng $\mathrm{Li}$ and Kawano 1998 , one possible explanation for this could be that greater pressures resulted in more friction between the rotation and fixed parts of the sprinkler. 
Table 3. Index of Jet breaks up at various nozzle types at operating pressures $150 \mathrm{kpa}$

\begin{tabular}{|c|c|c|c|}
\hline Nozzle Number & Index of jet break up (Pd) & Reference range & performance \\
\hline 1 & 5.93 & & Unacceptable \\
2 & 5.92 & $2-4$ excellent & Unacceptable \\
3 & 4.43 & & Unacceptable \\
4 & 3.4 & $>4$ unacceptable & Excellent \\
\hline
\end{tabular}

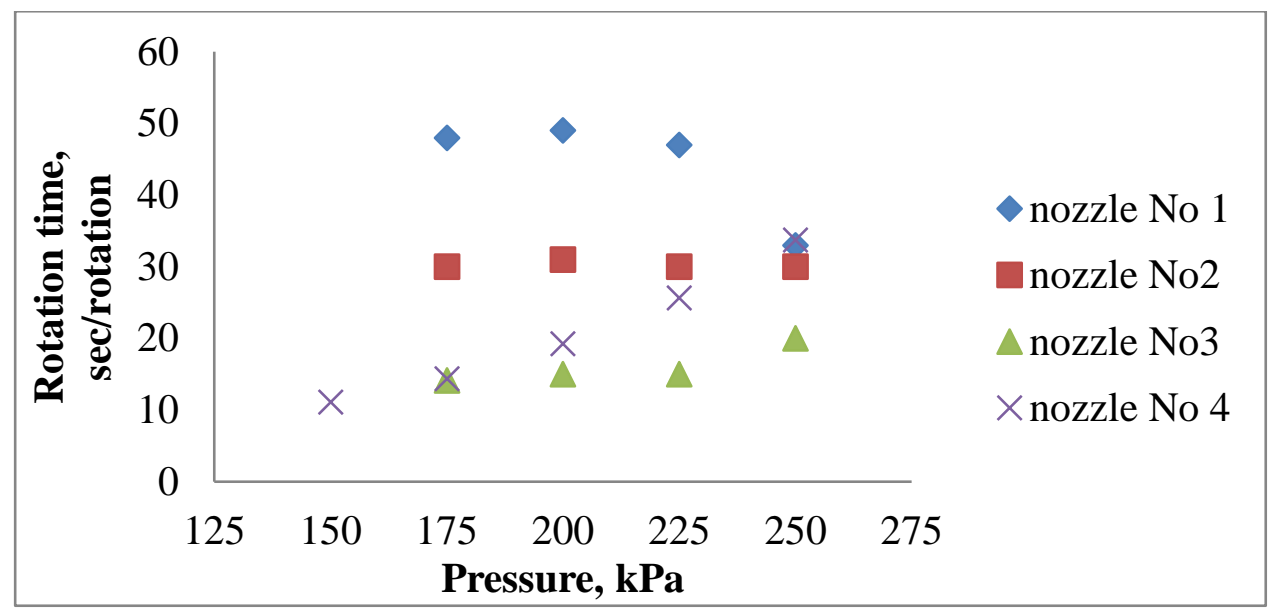

Fig 7. Rotation time for different nozzles at different operating pressure

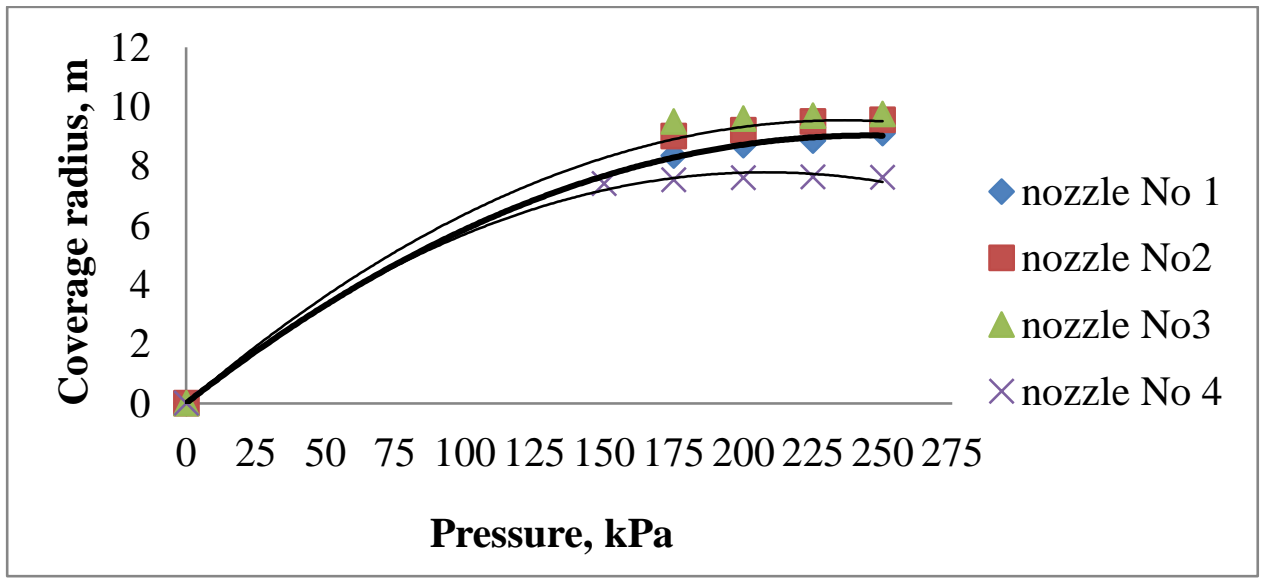

Fig 8. coverage radius for different nozzles vs. operating pressure 

sprinkler irrigation system

The previous figures show that the coverage radius followed the normal pattern with increasing operating pressure also with increasing the nozzle diameter the coverage increase which may be because of throw velocity. The coverage radius figures also show that the highest radius was obtained by nozzle No. 3 with $9.75 \mathrm{~m}$ at operating pressure 250 $\mathrm{kPa}$.

From Fig. 8 appears the maximum droplet diameter indicated from nozzle No. 3 because of nozzle characteristics which agree with Hashem et al (2009) Droplet sizes for noncircular nozzles were compared with the traditional circular nozzle were larger for noncircular nozzles at a given distance from the sprinkler, Where the droplet diameter on the outer perimeter of the pattern.
The uniformity of nozzle No 3 was the highest value at operating pressure $175 \mathrm{kPa}$ but also nozzle No 4 achieve acceptable uniformity but at operating pressure $150 \mathrm{kPa}$. So we can deduce that, the irrigation uniformity of sprinkler irrigation system was more affected by the combination of operating pressure and nozzle characteristic, when the pressure and nozzle area increased the irrigation uniformity increased. The decrease of uniformity may be due to non-uniform water distribution where the jet broke up too much as it was proved from index break jet.

It was found for nozzle No. 4, achieving acceptable uniformity according to ASABE 2001, the suitable operating pressure was $150 \mathrm{kPa}$ not less than this. So it will save operating time with reducing ratio between nozzle No. 4 to No. $326.87 \%$.

Table 4. The calculated and measured droplet size diameter for different droplet diameter measured methods

\begin{tabular}{|c|c|c|c|c|}
\hline $\begin{array}{c}\text { Droplet weight, } \\
(\mathbf{g})\end{array}$ & $\begin{array}{c}\text { Droplet volume, } \\
(\mathbf{m m} 3)\end{array}$ & $\begin{array}{c}\text { Measured droplet } \\
\text { diameter }(\mathbf{m m})\end{array}$ & $\begin{array}{c}\text { Camera droplet } \\
\text { diameter, }(\mathbf{m m})\end{array}$ & $\begin{array}{c}\text { Paper droplet } \\
\text { diameter, }(\mathbf{m m})\end{array}$ \\
\hline 0.046 & 46 & 4.44 & 4.45 & 4.5 \\
\hline
\end{tabular}

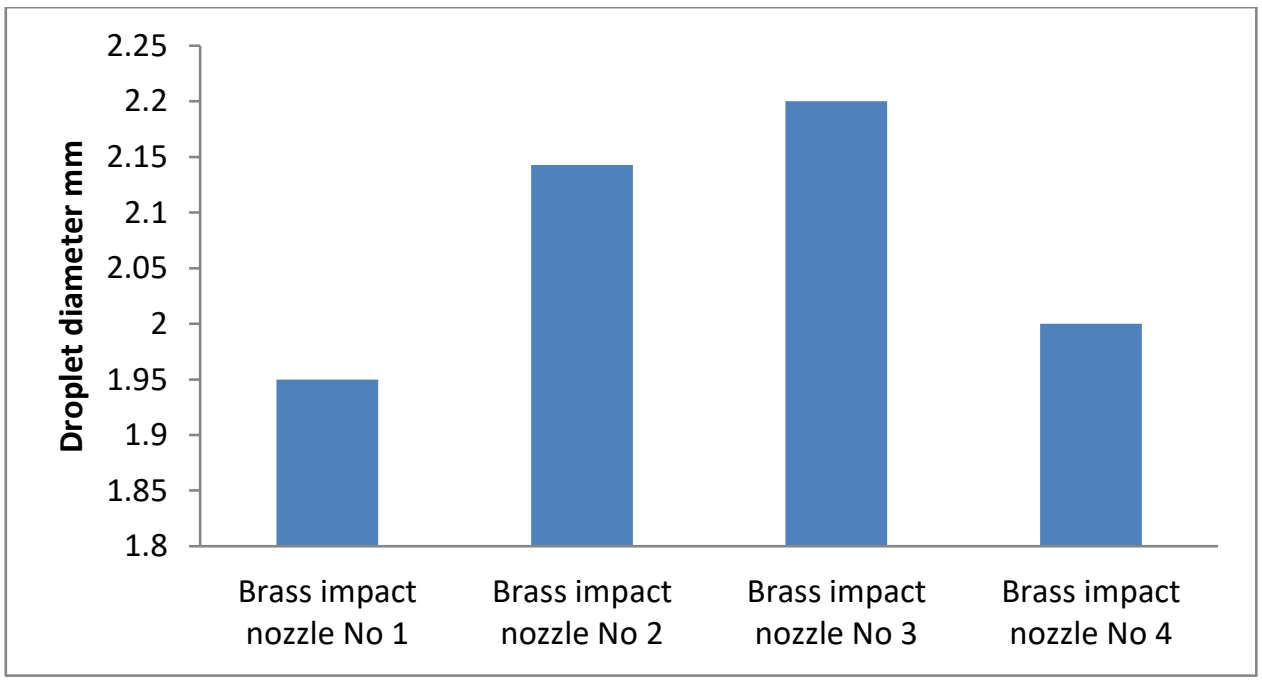

Fig 9. Average Camera droplet diameter at operating pressure $175 \mathrm{kPa}$ for different nozzles 

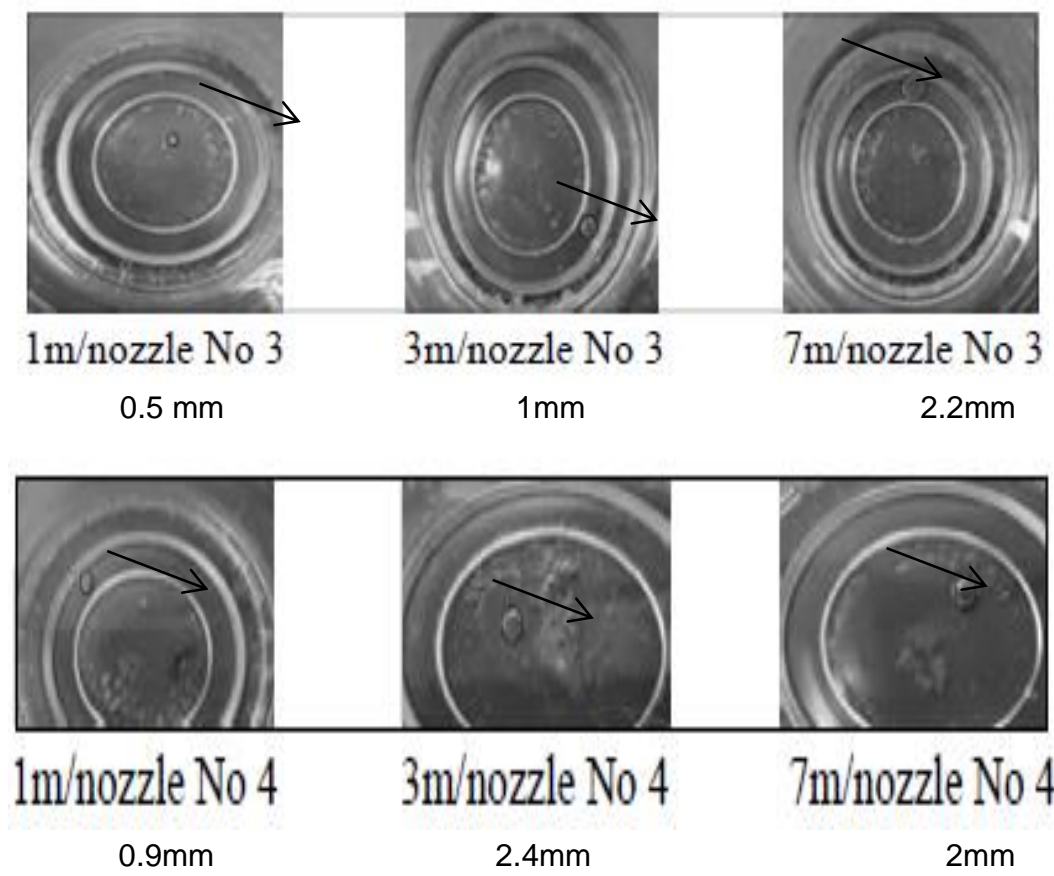

Fig 10. Camera droplet diameter at operating pressure $175 \mathrm{kPa}$ for nozzles 3 and 4 at different distance from sprinkler

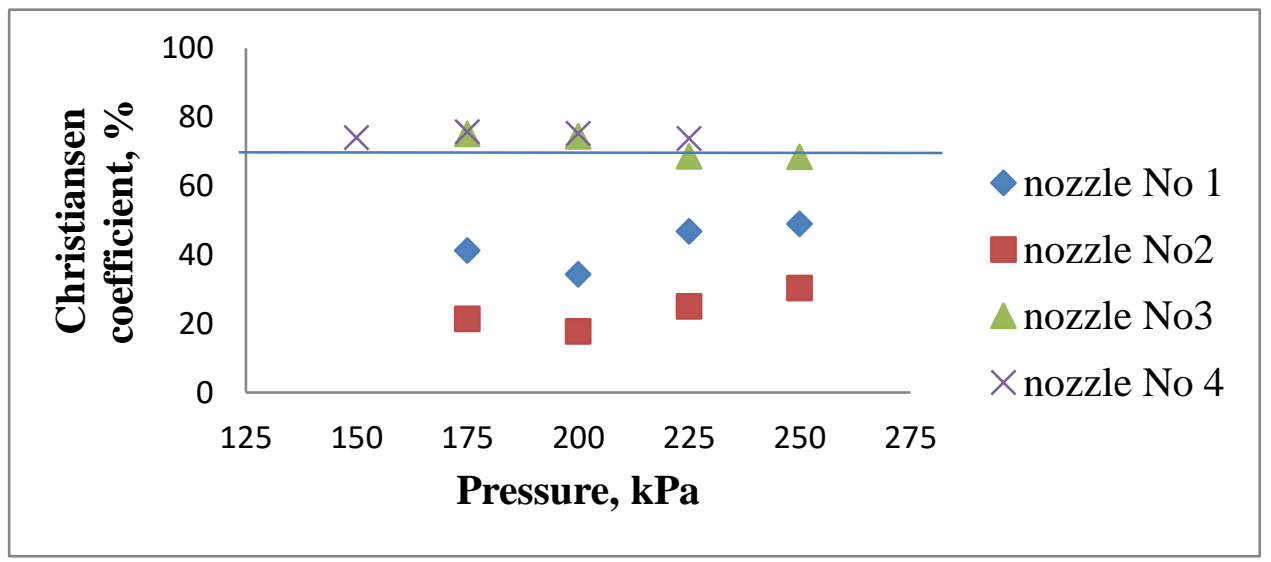

Fig 11. Christiansen coefficient for different nozzles vs. operating pressure for single impact sprinkler

\subsection{Comparing between Hedia Program and ac- tual overlapping}

The overlapping is one of the important engineering design factors that affects the sprinkler irrigation system performance.

It was found that nozzle No. 4 at $9 \times 9$ overlapping ratio had acceptable uniformity according to ASABE 2001 and achieved the highest precipitation rate $3.78 \mathrm{~mm} / \mathrm{hr}$ at actual experiments.
Also it was found that the difference ratio between Program and actual experiment was increasing in Christiansen coefficient $14.57 \%$ and decreasing in precipitation rate $6.93 \%$. It may be because of rotation speed and contraction angle is not taking in the program mind which influencing instantaneous application intensity and the water distribution pattern as mention by (Jiusheng and Kawano 1998).

$12 \times 12$ overlapping at sprinkler base pressure $150 \mathrm{kPa}$ (operating time (hour)). 

sprinkler irrigation system

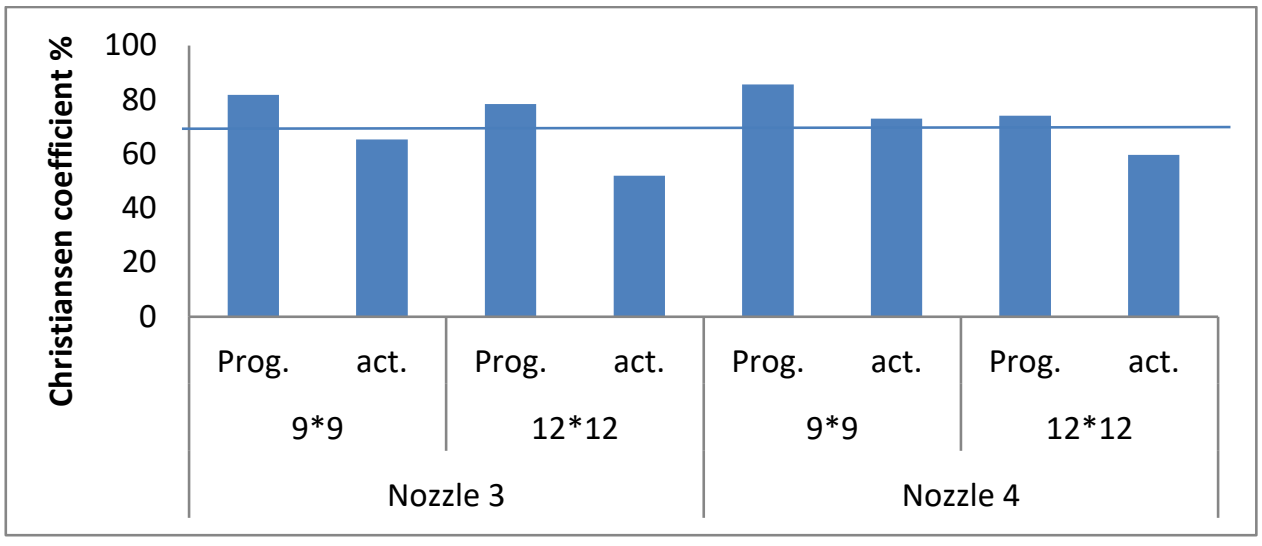

Fig 12. Christiansen coefficient for nozzles 3 and 4 at operating pressure $150 \mathrm{kPa}$ vs. overlapping ratio comparing between HEDIA program and actual experiment

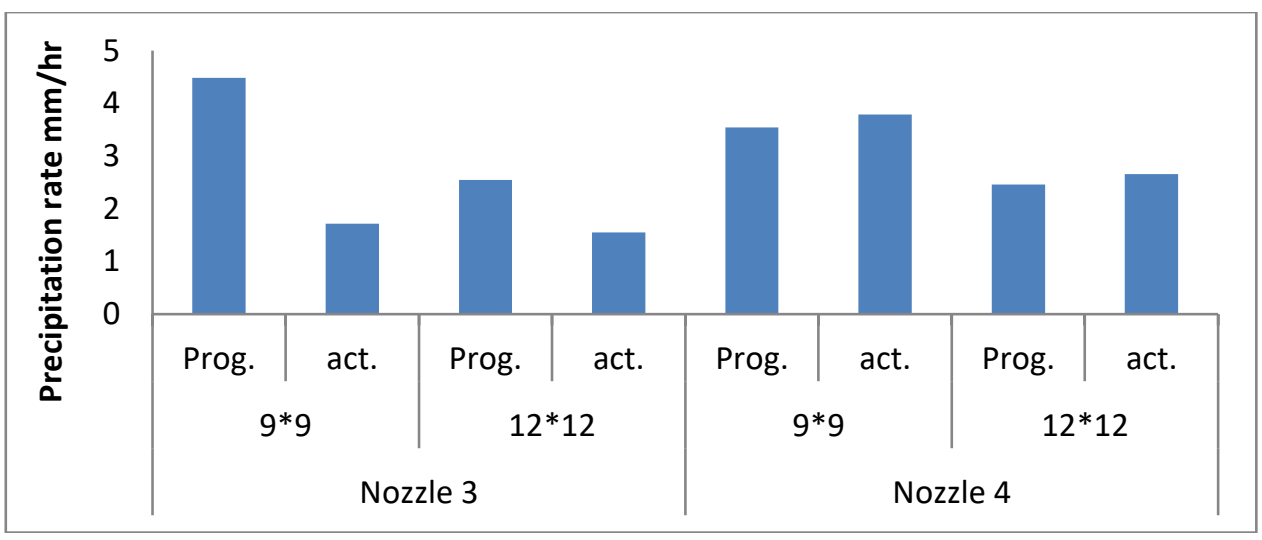

Fig 13. Christiansen coefficient for nozzles 3 and 4 at operating pressure $150 \mathrm{kPa}$ vs. overlapping ratio comparing between HEDIA program and actual experiment

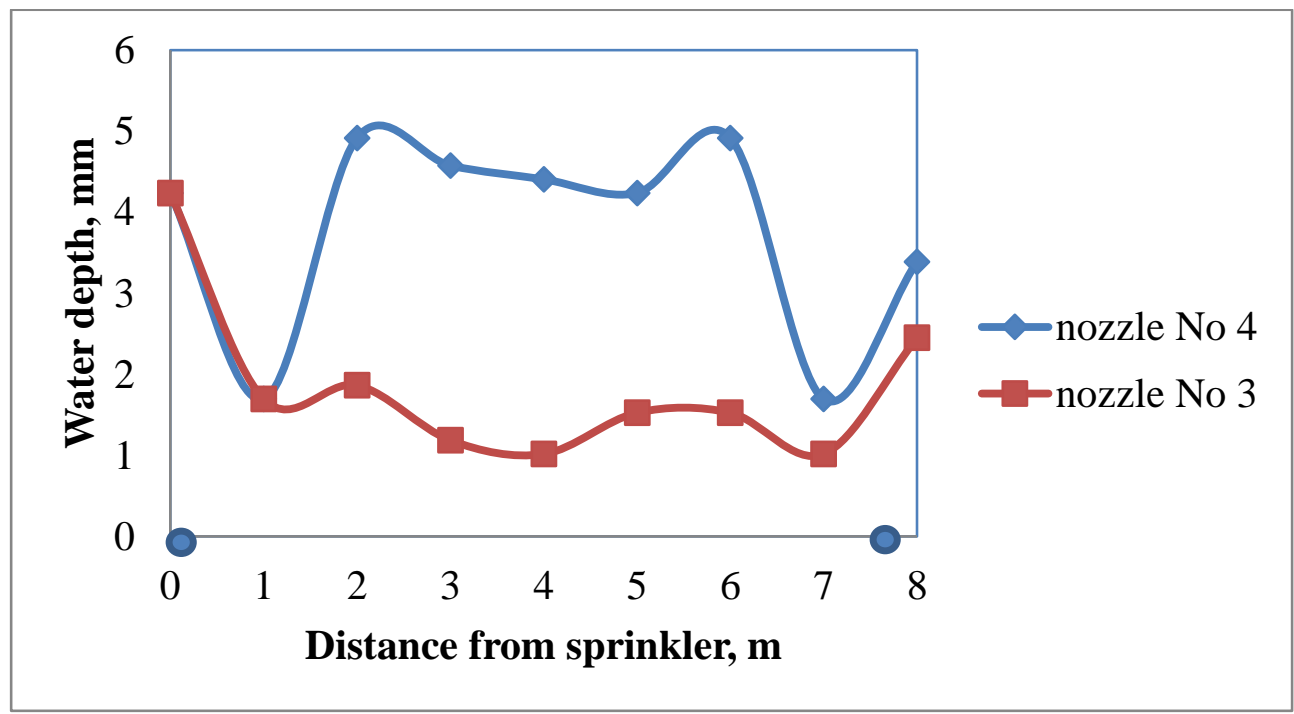

Fig 14. Water application profiles for circular nozzle No4 and square orifices nozzle No. 3 with 9X9 overlapping at sprinkler base pressure $150 \mathrm{kPa}$ (operating time (hour)) 


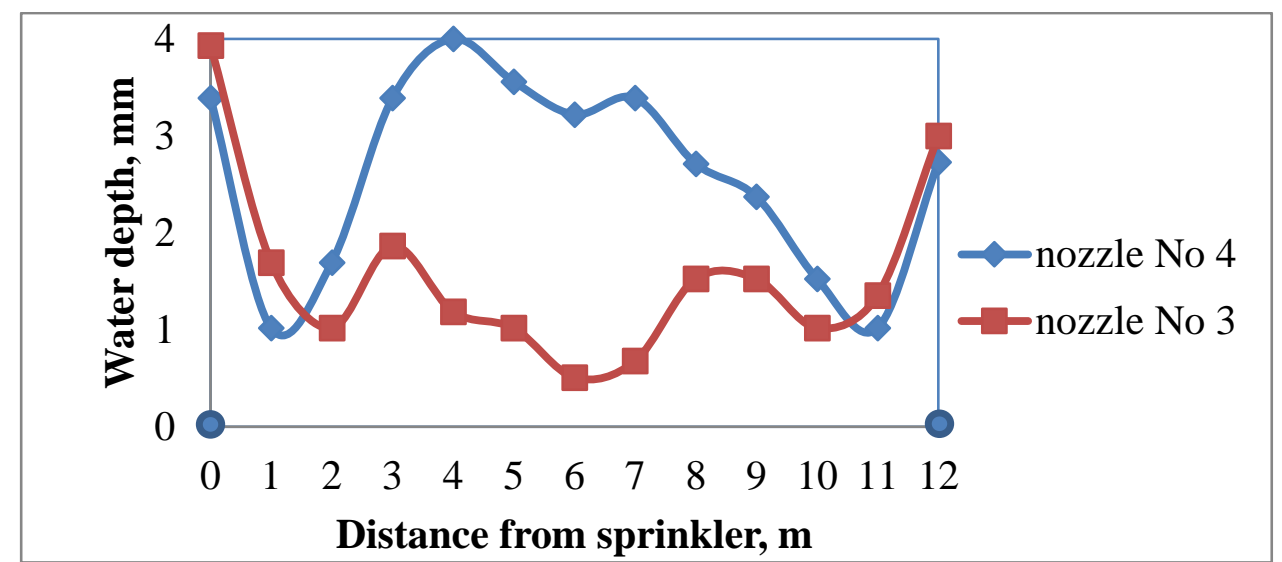

Fig 15. Water application profiles for circular nozzle No4 and square orifices nozzle No. 3 with

The charts 14 and 15 indicated that the nearly horizontal pattern gradually to rectangular shape with pull out in the water throw from the sprinkler gave more water uniformity for nozzle No. 4 with circular orifice unlike nozzle No. 3 with square orifice show doughnut pattern. The water application profiles for nozzle No. 4 further increased gradually in the middle distance between sprinklers than near the sprinkler while nozzle No 3 was higher near the sprinklers than in the middle in between the sprinklers, corresponding to large mean droplet diameter.
The maximum percentage of over irrigation for nozzle No. 3 near the sprinkler reaches to $416.67 \%$ more than the targeted irrigation depth near the sprinkler. For the time being with nozzle No. 4 these areas reduced received water by $66.7 \%$ of nozzle No. 3 at $9 \times 9$ overlapping distance.

The maximum percentage of over irrigation for nozzle No. 3 near the sprinkler reaches to $773.33 \%$ more than the targeted irrigation depth. For the time being with nozzle No. 4 these areas were reducing received water by $132 \%$ of nozzle No. 3 at $12 \times 12$ overlapping distance.

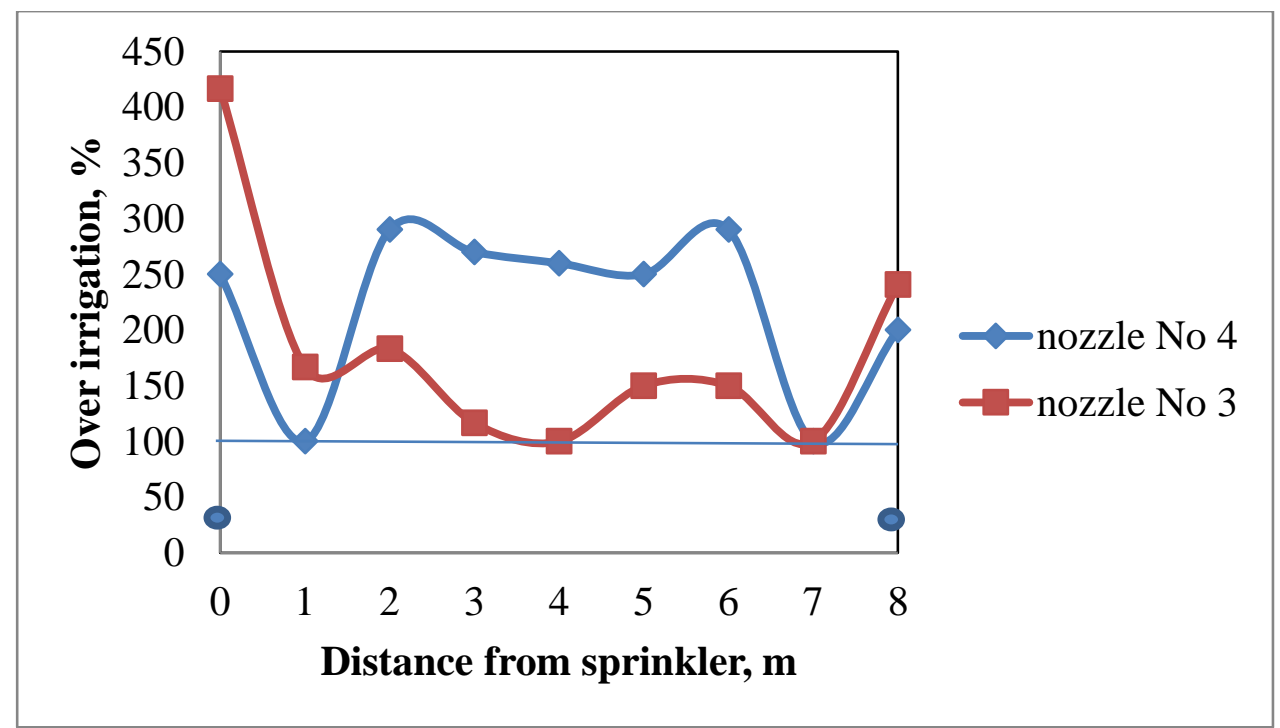

Fig 16. Water application profiles for circular nozzle No4 and square orifices nozzle No. 3 with $9 \times 9$ overlapping at sprinkler base pressure $150 \mathrm{kPa}$ 


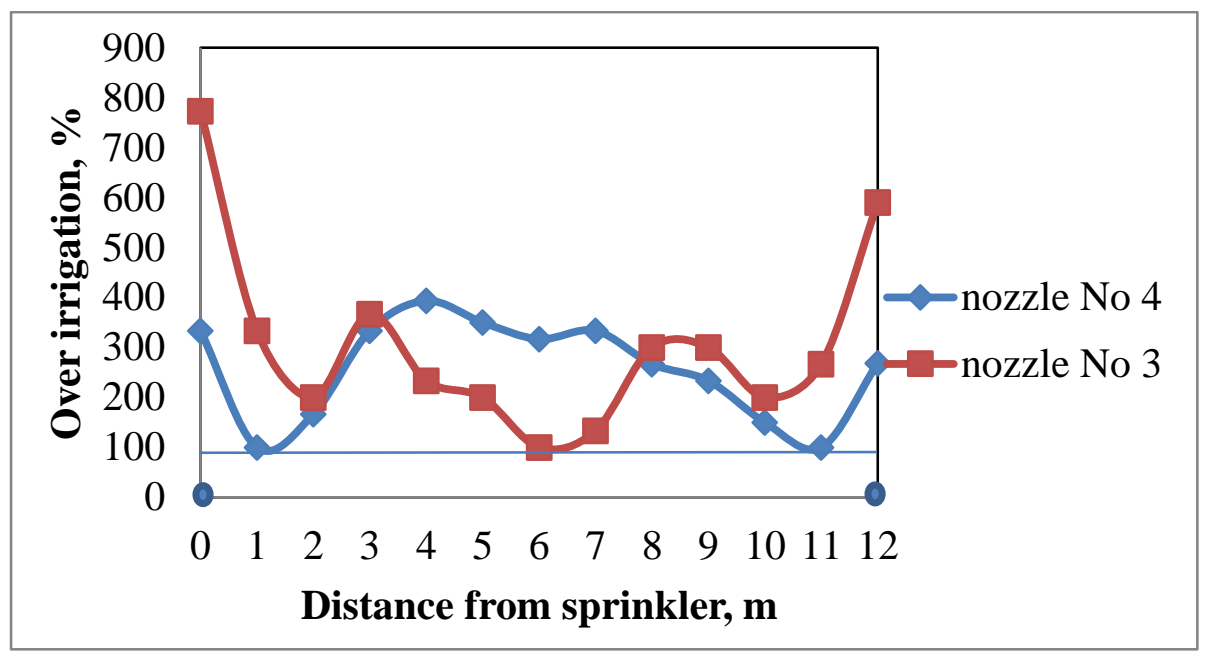

Fig 17. Water application profiles for circular nozzle No4 and square orifices nozzle No. 3 with $12 \times 12$ overlapping at sprinkler base pressure $150 \mathrm{kPa}$

\section{Conclusion}

This study compared hydraulic performance for different nozzle characteristic. Generally the orifice diameter and nozzle path of nozzle No. 4 got more efficient water application profile with $9 \mathrm{mX} 9 \mathrm{~m}$ overlapping. At low pressure $150 \mathrm{kPa}$, Nozzle No 4 gave lower over irrigation percentage comparing with nozzle No. 3 by $66.7 \%$ at the same overlapping distances and at the same operating pressure 150 $\mathrm{kPa}$. Nozzle No 4 had acceptable coefficient of uniformity at operating pressure $150 \mathrm{kPa}$ instead of nozzle No. 3 at operating pressure $175 \mathrm{kPa}$. Meanwhile it was found that nozzle 1 and 2 had unacceptable uniformity coefficient so it should be increased operating pressure over $250 \mathrm{kPa}$ or decreased the distance between sprinklers to achieve acceptable performance. Finally, at lower operating pressure using nozzle No. 4 achieved saving operating time ratio by $26.87 \%$.

The study recommends the use of the nozzle No 4 to reach an appropriate performance as well as an appropriate uniformity coefficient (not less than 70\% as recommended by ASABE 2001) when operating at a low pressure to provide the energy needed for operation. Besides, research should be continued in developing the nozzle design to increase the coverage radius while facilitating the inclusion of the appropriate design in the system according to the irrigated ground conditions, available energy, and the conditions around the sprinkler. It is also recommended to adjust the simulation program to conform to the different nozzles specifications that affect the dissipation of the water outlet Kinetic energy which in turn affects the sprinkler performance.

\section{Reference}

Abdel-mageed, HM; El-Berry, AM; Ramadan, $\mathrm{MH}$; El-Adl MA 2009. Computer modeling for design and performance of on-demand low pressurized irrigation systems, PhD Thesis of Agricultural Engineering, Agric Engineering Dept, Fac of Agric, AlMansoura Univ, Al-Mansoua Egypt $44 \mathrm{p}$.

ASABE (2001) Test procedure for determining the uniformity of water distribution of center pivot and lateral move irrigation machines equipped with spray or sprinkler nozzles. ANSI/ASABE Standard S436.1, American Society of Agric Engineers St. Joseph MI.

Dwivedi, DK; Gontia, NK; Chavda, JM (2015) Hydraulic performance evaluation of mini sprinkler system. Afr J Agric Res 10, 4950-4966.

FAO, Food and Agriculture Organization of the United Nations, 2015, FAO Statistical Pocket Book. World, Food and Agriculture. FAO, Rome. 38 p.

Hedia, A; Abd El-Mageed, HN; Ibrahim, MM; Abd El-Mageed, HM (2017) Simulating the overlapping patterns of irrigation sprinklers using computer model. J Soil Sci and Agric Eng 8, 497-508. 
Jiusheng, L, Yingneng, L; Kawano, H (1995) Design Parameters of Double Rectangular Nozzles with Impact Sprinkler, J of Irrigation Engineering and Rural Planning 29, 66-77.

Jiusheng, L; Kawano, H (1998) Sprinkler Performance as affected by nozzle inner contraction angle. Irrigation Sci 18, 63-66.

Khadra, R; Lamaddalena, N; Inoubli, N 2013. Optimization of on demand pressurized irrigation networks and on-farm constraints, Procedia Environmental Sci, 19, 942-954, Elsevier B.V Open access under CC BY-NC-ND license. Selection and/or peer-review under responsibility of the Scientific Committee of the Conference doi: 10.1016/j.proenv.2013.06.104.
Osman, M; Hassan, S; Yusof, KW (2014) Effect of low pressure on irrigation uniformity of solid set sprinkler irrigation system. Applied Mechanics and Materials 567, 26-31. 10.4028/WWW.SCIETIFIC.NET/AMM.567.26.

Robles, O; Playán, E; Cavero, J (2017) Assessing low-pressure solid-set sprinkler irrigation in maize, Agric. Water Management 191, 37-49.

Stambouli, T; Zapata, N; Faci, JM (2014) Performance of new agricultural impact sprinkler fitted with plastic nozzles. Bio-systems Engineering 118, 39-51. 
مجلة اتحاد الجامعات العربية للعلوم الزراعية، جامعة عين شمس، القاهرة، مصر

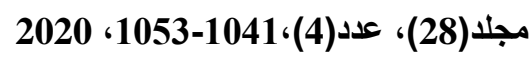

Website: http://ajs.journals.ekb.eg

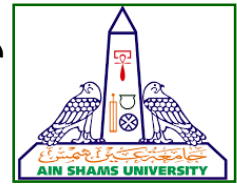

1053

تأثير تصميم الفوهات على آداء الرشاشات التصادمية في نظام الري بالرش

[73]

إنجى مسلم محمد خير1" - محمود محمد حجازى2 - خالد فران الباجورى2 - مائل محمود سلطان 1

1- قسم بحوث هندسة الري والصرف الحقلى - معهد بحوث الهندسة الزراعية - مركز البحوث الزراعية - الدقى - مصر مدرد

2- قسم الهندسة الزراعية الوراثة - كلية الزراعة - جامعة عين شمس - ص.ب 68 - حدائق شبرا 11241 - القاهرة -

مصر

*Corresponding author: engymosalem@egr.asu.edu.eg

Received 29 July, 2020

Accepted 10 October, 2020

التشغيل والطاقة. تحقيق الأنتظامية المناسبة تحت نسب

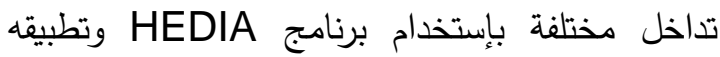
فعلياً. وقد جد أن الفوهة رقم 4 تزيد من معدل التدفي

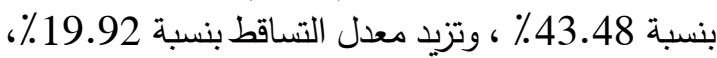

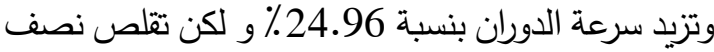

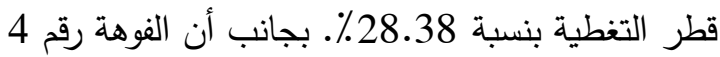

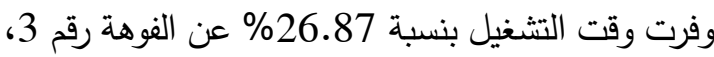

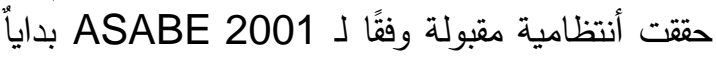
من ضغط تثغيل 150 كيلو باسكال. بعد التجربة لئلة العملية، يفضل وضع الفوهة رقم 4 على مسافات تداخل

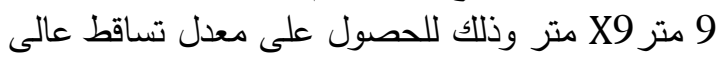
3.78 ملليمتر /ساعة ومقبولة أنتظاميتة 73.13\%

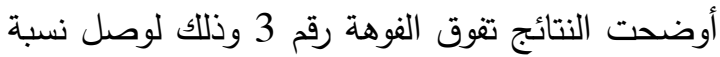

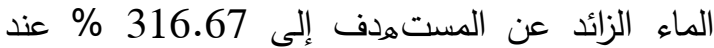
مسافات تداخل 9X9 بينما للفوهة رقم 4 فتقلصت مقدار المياه المستلمة بنسبة 66.7\% عند نفس مساف مسافات التداخل وعند نفس ضغط التشغيل 150 كيلو بسكال.

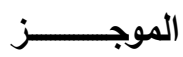

تلعب العوامل التصميمة الهندسية للفوهة دور هام

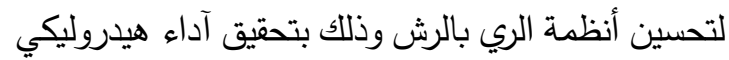
مناسب. لذلك تستهدف هذه الدراسة بعض الترف العوامل الهندسية التصميمية مثل (شكل الفوهة) وضغط التشغيل

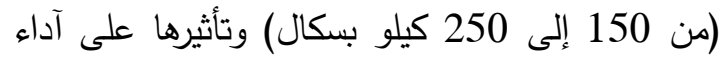

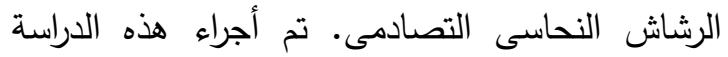
بمنطقة الجيزة بالمعمل القومى لأختبار مكونات شبكات التهات الرى والصرف الحقلى بمعهد بحوث الهندسة الزراعية.

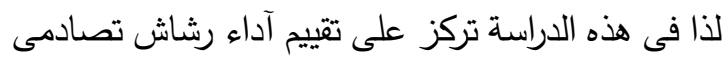
نحاسى منفردا تحت ضغوط تشغيل تركيل مختلفة وتحت تأثير

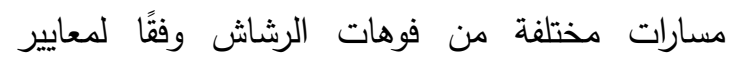
ASABE 2001 موقع فوهة الرش على ارتفاع 1 متر فوق مستوى سطح الأرض. دراسة تأثيرتطوير فوهة الرشاش (شكل المخرج

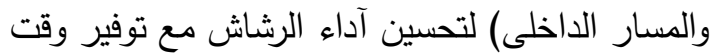

